Open Access

Res. Agric. Livest. Fish.

Short Article

Vol. 2, No. 1, April 2015: 75-77

\title{
SCREENING OF CARROT LINES FOR QUALITY ROOTS AND HIGHER YIELD FOR COMMERCIAL CULTIVATION
}

\section{Md. Mahfuzur Rahman* and Md. Abid Hasan}

Research and Development Department, Ispahani Agro Ltd., Rangpur-5402, Bangladesh

*Corresponding author: Md. Mahfuzur Rahman; E-mail: r.gitla@gmail.com

\section{ARTICLE INFO ABSTRACT}

Received

23.03.2015

Accepted

12.04.2015

Online

19.04.2015

Key words

Carrot

Quality root

Yield
The experiment was conducted at Research and Development (R\&D) farm of Ispahani Agro LTD., Rangpur in order to screen suitable carrot lines for commercial cultivation in Bangladesh. Two hybrid lines (02001 and 02002) and four open pollinated lines (01001, 01002, 01003 and 01004) were used in this screening program. The experiment was carried out following randomized complete block design with three replications. Results showed that root length and diameter of line 01004 were 14.66 and $3.580 \mathrm{~cm}$, respectively. The standard weight of 5 roots was $519.3 \mathrm{~g}$. Moreover, the line 01004 showed maximum quality roots and yield as compared to any other lines. This line is therefore can be recommended for commercial cultivation in Bangladesh.

To cite this article: MM Rahman and MA Hasan. 2015. Screening of carrot lines for quality roots and higher yield for commercial cultivation. Res. Agric. Livest. Fish. 2 (1): 75-77. 


\section{INTRUDUCTION}

Carrot (Daucus carota var. sativus) is a member of the Apiaceae family (Peirce, 1987). It is probably originated in Asia around northwest India. Cultivation of roots for consumption has been started from 600 A.D. in Afghanistan (Kelley et al., 2012). Now a days, carrot production spreads worldwide due to its nutritive value (Yawalker, 1985). The cylindrical yellow colored carrots get priority in Bangladesh due to its attractiveness among the four basic types. All the commercially grown carrot varieties in Bangladesh are generally of the importer type. Numerous commercial varieties exist and imported by different seed companies. Although yield is an important criterion to the farmer for selecting variety for production, it should not be the only selection criteria (Kelley et al., 2012). Therefore, the study has undertaken in order to evaluate yield and yield contributing characters of some selected carrot lines in Bangladesh condition as well as study the suitability of these lines for commercial cultivation in Bangladesh.

\section{MATERIALS AND METHODS}

The experiment was carried out at Research and Development (R\&D) farm of Ispahani Agro LTD., Rangpur during 04 November, 2013 to 20 February, 2014. Two hybrid lines (02001 and 02002) and four open pollinated lines (01001, 01002, 01003 and 01004) were used as experimental material. The unit plot size was $1 \mathrm{~m} \times 5.6 \mathrm{~m}$. The selected land was well drained, medium high and the soil was loamy textured. The experiment was laid out in randomized complete block design with three replications. The experimental plot was prepared by good tilth and fertilized with recommended doses of manures and fertilizers. The intercultural operations were done as similar to farmers practice.

Data were recorded on quality contributing characteristics from five randomly selected plants, yield and yield contributing characters from total harvest scenario and were analyzed statistically by MSTATc Version 1.2. The difference between the treatments was adjudging by least significance difference test.

\section{RESULTS AND DISCUSSION}

Root weight (Northolt et al., 2004), root length and root diameter is considered as the root quality contributing characters. Root length was found highest $(14.66 \mathrm{~cm})$ in 01004 which show significantly higher than any other varieties. On the other hand, root diameter was highest in line $02001(3.593 \mathrm{~cm})$ which is statistically similar with lines $01001(3.60 \mathrm{~cm})$ and $01004(3.58 \mathrm{~cm})($ Table 1). Line 01004 again showed maximum weight of 5 standard roots with significant difference from any other lines. From the quality contributing characters, line 01004 contains good root quality than any other OP and hybrid variety.

Table 1. Quality and yield contributing characters of different carrot lines

\begin{tabular}{|llllll|}
\hline Acc. code & $\begin{array}{l}\text { Root length } \\
(\mathbf{c m})\end{array}$ & $\begin{array}{l}\text { Root diameter } \\
(\mathbf{c m})\end{array}$ & $\begin{array}{l}\text { Weight of 5 } \\
\text { standard root(g) }\end{array}$ & $\begin{array}{l}\text { No. of rootsl } \\
\text { plot }\end{array}$ & $\begin{array}{l}\text { Yield/Ac. } \\
\text { (tons) }\end{array}$ \\
\hline 02001 & 12.17 & 3.593 & 479.7 & 149 & 7.893 \\
02002 & 13.30 & 3.360 & 468.3 & 150 & 8.000 \\
01001 & 12.20 & 3.600 & 481.0 & 149 & 7.613 \\
01002 & 12.30 & 3.180 & 443.0 & 137 & 6.823 \\
01003 & 12.00 & 3.200 & 409.7 & 159 & 7.753 \\
01004 & 14.66 & 3.580 & 519.3 & 155 & 7.777 \\
LSD (0.05) & 0.2179 & 0.1488 & 44.70 & 29 & 1.890 \\
Level of & $*$ & $*$ & NS & NS & $*$ \\
significance & & & & & \\
\hline
\end{tabular}

* indicates significant at $5 \%$ level of significance, $N$ indicates non-significant at $5 \%$ level of significance Number of roots/bed in each line had no difference statistically and also in yield/Ac (Table 1). 


\section{CONCLUSION}

Line 01004 produced maximum quality roots and the yield is similar to the hybrid lines statistically. Therefore, the line 01004 should be best suited for commercial cultivation in terms of quality yield and will minimize the cost of production.

\section{REFERENCES}

1. Peirce LC, 1987. Vegetable: Characteristics, production and marketing. John Wiley and Sons. Inc. New York. pp: 251-252

2. Kelley WT, G MacDonald, and SC Phatak, 2012. Commercial Production and Management of Carrots. CAES Publications.

3. Yawalker KS, 1985. Vegetable crops in India. Third edition. Mrs. K.K. Yawalker, Agri-Horticultural Publishing House, 52, Bajaj Nagar-440010. pp: 210-220

4. Northolt M, GJVD Burgt, T Buisman and AV Bogaerde, 2004. Parameters for carrot quality. Louis Bolk Instituut. 